ISSN: 2224-0616

Int. J . Agril. Res. Innov. \& Tech. 7 (1): 46-50, J une, 2017

Available online at http:// www.ijarit.webs.com

\title{
PARENTAL LINE SELECTION FOR YIELD CONTRIBUTING CHARACTER OF RICE (Oryza sativa)
}

\author{
M.S.H. Bhuiyan'*, M.A. Malek' ${ }^{2}$, M.F. Ikbal', A. Topu ${ }^{3}$ and A.B.M.S. Alam ${ }^{4}$ \\ Received 18 April 2017, Revised 24 May 2017, Accepted 26 June 2017, Published online 30 June 2017
}

\begin{abstract}
The prime objective of any hybrid program is to bring the desirable genes present in the parent into a single genetic background. Therefore, an experiment was conducted to evaluate the parental performance at the experimental farm of Bangabandhu Sheikh Mujibur Rahman Agricultural University. Nine A (male sterile) lines and Four R (restoral) lines were used here. To consider their performance various agronomic trait was selected and most emphasis was provide for plant height, days to maturity and other yield contributing character. The characters studied in this investigation exhibited low to moderate range of variability and heritability. Out of all RGBU0014A perform the height days to maturity then others. Although yield is more or less similar for the restorer parent, but considering other agronomic yield contributing trait RGBU003A, RGBU002A, RGBU009A can be selected to cross with superior restoral SL8 R and Mitali R to obtain ideal plant type.
\end{abstract}

Keywords: Rice, Restorer Line, Female Parent, Yield Performance

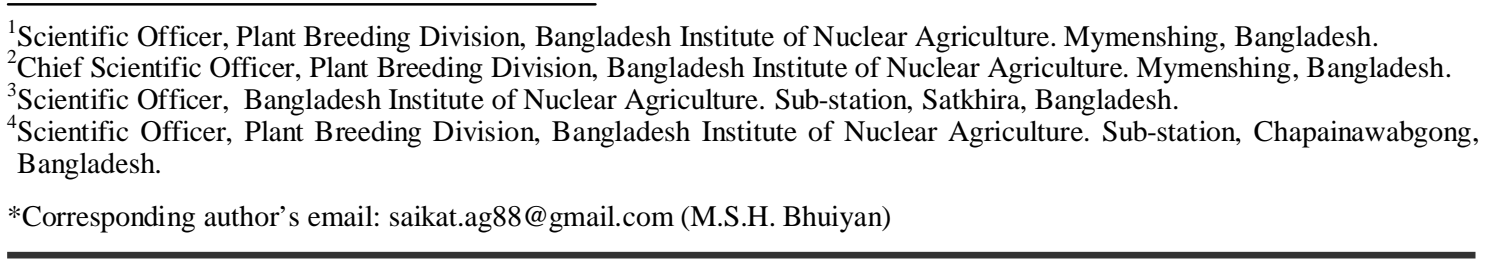

Introduction

Rice is self-pollinated cereal crops belongs to the genus Oryza and has two cultivated and 22 wild species. The cultivated species are Oryza sativa and Oryza glaberrima. Oryza sativa is grown all over the world and originated from Indo-china region i.e., Assam, Bangladesh, Burma, Thailand, Laos, Vietnam while Oryza glaberrima has been cultivated in West Africa for the last 3500 years. It has been cultivated as major crops for more than 7000 years (Singh, 2000).

Rice is central to the lives of billions of people around the world. Possibly the oldest domesticated grain $(10,000$ year). Rice is the most important food crop and the staple food for $40 \%$ of the world population. More than $90 \%$ of rice is produced and consumed in Asia (Virmani, 1996). With the increasing population pressure the demand of cereal is increased day by day. The world population expected to reach 8 billion in 2025 and it is estimated that $50 \%$ more food is required to feed the increased population (Brown, 1994). In Bangladesh, about $80 \%$ of the total cultivation lands are used for rice cultivation and the total production is 29.74 million metric tons (Anonymous, 2010). At present in Bangladesh, the area under rice cultivation is gradually decreasing due to industrialization and expansion of urban area. The population continues to grow but arable land area is shrinking.
A lot of rice land is being converted to non-rice uses. If production has to be increased, the only way we can do to meet this challenge is by increasing the yield per unit area and a solution to this is with the use of hybrid varieties. For this yield potentiality of rice need to be increased to get more yields per unit area, so hybrid development may be one of the ways to satisfy the future demand.

Hybrid rice breeding aims to improve the desirable characters of parental lines and ultimately the yield performance of their $F_{1}$ hybrids. Hybrid rice breeding involves: i) improvement of parental lines and ii) development and evaluation of rice hybrids. To achieve its goal, it requires construction of basic breeding populations, continuous identification and selection of potential parental lines, further purification of the lines, and evaluation of field performance of $F_{1}$ hybrids. The selection of parental lines plays a vital role in developing ideal combinations. Careful selection of maintainer and restorer lines may lead to the development of hybrids with higher yield potential than parents and standard check varieties. Selection of parent for higher magnitude for yield traits and utilization of that in varietals development are the possible approaches to increase the yield. There for the objective of this study was selection of 
superior parental line for future use as a crossing material.

\section{Materials and Methods}

An experiment was conducted to evaluate the parental performance at the experimental farm of Bangabandhu Sheikh Mujibur Rahman Agricultural University, Salna, Gazipur during December 2012 to July 2013. The experimental site is located at the centre of Madhupur Tract $\left(24^{\circ} 09^{\prime} \mathrm{N}\right.$ latitude and $90^{\circ} 26^{\prime} \mathrm{E}$ longitude) having an elevation of 8.2 meter from sea level (Anonymous, 1989). Nine A lines and Four $\mathrm{R}$ lines were used here namely RGBU002A, RGBU003A, RGBU005A, RGBU006A, RGBU009A, RGBU010A, RGBU012A RGBU013A, RGBU014A as a meal sterile line and SL8R, LP70R, Gold R and Mitali R as a restorer line. Four different maintainer line was also used here (data was not present here).

The experiment was laid out in a Randomized Complete Block Design (RCBD) with three replications. The experimental area was divided into three blocks, representing three replications.
Five rows of $4 \mathrm{~m}$ each constituted the experimental unit. Treatment was distributed in the experimental unit through randomization by using the MSTAT program.

Data was taken from five parent for all yield contributing character namely plant height, number of effective and ineffective tiller, days to maturity, length of normal leaf, flag leaf, length of panicle, number of primary and secondary branch/panicle and yield. Earlier it was mentioned that two type of parent (male serial and restorer) was taken for this experiment so we need extra care for collecting data. When we consider effective tiller, we consider panicle bearing one although it was sterile, and for fill and unfilled grain, we take restorer line only our consideration.

\section{Results and Discussion}

From the analysis of variance table it is clear that all agronomic character other than yield have significant effect, so every character have individual importance in selection process.

Table 1. Analysis of variance for yield and yield related character in rice.

\begin{tabular}{|c|c|c|c|c|c|c|c|c|c|c|c|c|c|}
\hline $\begin{array}{l}\text { Source of } \\
\text { Variation }\end{array}$ & $\overline{\mathrm{Df}}$ & $\overline{\mathrm{PH}}$ & $\mathrm{ET}$ & IET & LNL & LFL & LP & $\overline{D M}$ & NPB & NSB & $\mathrm{NFG}$ & $\overline{\text { NUG }}$ & Yield \\
\hline Parent & 12 & $5.21^{*}$ & $38.34 * *$ & $57.26^{* *}$ & $55.21 * *$ & $30.32^{* *}$ & $9.18 *$ & $236.77^{* *}$ & 8.56* & 137.30** & $305.47 * *$ & $38.08^{* *}$ & 0.04 \\
\hline
\end{tabular}

* indicates significant at $1 \%$ level, **indicates significant at $5 \%$ level, $\mathrm{PH}=$ Plant Height $(\mathrm{cm}), \mathrm{ET}=$ No. of Effective Tiller, IET= No. of ineffective Tiller, LNL= Length of Normal Leaf, LFL=Flag leaf length, DM= Days to maturity, NPB= No. of primary Branches/panicle, NSB= No. of Secondary Branches/panicle, NFG= No. of filled grains / panicle, NUG= No. of unfilled grains/panicle.

\section{Variable Parameters}

The main objectives of plant breeder are to collect and present the genetic variability to make up it available for present and upcoming generation.
GCV and PCV values were classified as low (0$10 \%)$, moderate $(10-20 \%)$ and high $(20 \%$ and above).

Table 2. Estimation of genetic component of variation of yield contributing characters for male sterile line (A line).

\begin{tabular}{|c|c|c|c|c|c|c|c|c|}
\hline Yield contributing characters & VG & $\mathrm{VE}$ & VP & GCV & GPV & GEV & $\mathrm{h}^{2} \mathrm{~B}$ & GA \\
\hline Plant height & 13.27 & 3.40 & 16.67 & 3.91 & 4.38 & 1.98 & 79.60 & 6.70 \\
\hline Effective tiller & 4.61 & 1.35 & 5.96 & 23.28 & 26.47 & 12.60 & 77.34 & 3.90 \\
\hline Length of normal leaf & 3.39 & 3.00 & 6.39 & 6.99 & 9.61 & 6.58 & 53.05 & 2.76 \\
\hline Length of flagleaf & 3.07 & 3.70 & 6.77 & 9.77 & 13.9 & 10.72 & 45.34 & 2.43 \\
\hline Length of panicle & 1.83 & 1.80 & 3.63 & 6.80 & 6.74 & 9.58 & 50.41 & 1.98 \\
\hline Days to initial flowering & 8.41 & 0.40 & 8.81 & 3.04 & 3.10 & 0.66 & 95.50 & 5.84 \\
\hline Days to maturity & 25.32 & 7.51 & 32.84 & 4.66 & 5.31 & 3.0 & 77.11 & 3.29 \\
\hline $\begin{array}{l}\text { No. of primary } \\
\text { branches/ panicle }\end{array}$ & 1.00 & 0.19 & 1.19 & 9.34 & 10.21 & 4.12 & 83.70 & 2.84 \\
\hline $\begin{array}{l}\mathrm{P}_{\mathrm{P}}=\text { Phenotypic component of } \\
J_{\mathrm{E}}=\text { Environmental component } \\
\mathrm{h}^{2} \mathrm{~b}=\text { Broad sense heritability }\end{array}$ & $\begin{array}{l}\text { ance } \\
\text { lance } \\
\text { rariance }\end{array}$ & & & \multicolumn{5}{|c|}{$\begin{array}{l}\text { GCV = Genotypic coefficient of variance } \\
\text { PCV = Phenotypic coefficient of variance } \\
\text { ECV = Environmental coefficient of variance } \\
\text { GA = Genetic advance }\end{array}$} \\
\hline
\end{tabular}

The characters studied in this investigation exhibited low to moderate range of variability. Out of all other parameter highest GCV and PCV values were obtained from the trait effective tiller number, in case of male sterile or A line. On the other hand, when we consider restoral or $\mathrm{R}$ line we find that moderate GCV and PCV values obtained from days to maturity and number of primary branch/panicle. Less of environmental variation indicates the presence of high genetic variability for that character. Therefore, selection based on phenotype alone can be effective for the improvement of these traits. This type of result also obtained from the experiment conducted by Sao (2002). 


\section{Heritability}

Like GCV and PCV heritability also classified as low (0-30\%), moderate (30-60\%) and high (above 60\%). The characters studied in this experiment expressed moderate to high heritability estimates ranging from $45.34 \%$ to $95.50 \%$. For male sterile line or A lines high heritability was recorded by days to initial flowering and number of primary branch/panicle followed by plant height, effective tiller number and days to maturity. For restoral line or R line used here high heritability was recorded for days to maturity, number of primary branch/panicle and number of number of filled grain/panicle. High heritability indicated that the characters under study are less influenced by environment. Therefore, plant breeder may make his selection safely based on phenotypic expression of these characters in the individual plant by adopting simple selection methods. High heritability indicates the scope of genetic improvement of these characters through selection process. Similar result has been reported by Babu et al. (2012).

\section{Genetic advance}

Heritability combined with genetic advance would give more reliable index of selection. In general, the characters that show high heritability with genetic advance are controlled by additive gene action and can be improved through simple or progeny selection method. Selection ability coupled with high genetic advance is likely to accumulate more additive genes leading to future improvement of their performance.

Table 3. Estimation of genetic component of variation of yield contributing characters for male sterile line (R line).

\begin{tabular}{|c|c|c|}
\hline Yield contributing characters & VG & VE \\
\hline Plant height & 10.30 & 3.25 \\
\hline Effective tiller & 6.34 & 1.89 \\
\hline Length of normal leaf & 4.12 & 2.95 \\
\hline f flag leaf & 3.17 & 3.70 \\
\hline Length & 4.97 & 2.05 \\
\hline Days to initial flowering & 1.96 & 0.32 \\
\hline maturity & 300.06 & 19.28 \\
\hline $\begin{array}{l}\text { No. of primary } \\
\text { branches/ panicle }\end{array}$ & 21.55 & 1.92 \\
\hline No. of filled grains/ panicle & 76.91 & 6.54 \\
\hline \multicolumn{3}{|c|}{$\begin{array}{l}V_{G}=\text { Genotypic component of variance } \\
V_{P}=\text { Phenotypic component of variance } \\
V_{E}=\text { Environmental component of variance } \\
h^{2} b=\text { Broad sense heritability }\end{array}$} \\
\hline \multicolumn{3}{|c|}{$\begin{array}{l}\text { In these studies, higher heritability along with } \\
\text { high genetic advance was noticed for the traits } \\
\text { effective tiller number. Other character showed } \\
\text { high heritability along with moderate or low } \\
\text { genetic advance which can be improved by } \\
\text { intermitting superior genotypes of segregating } \\
\text { population developed from combination breeding } \\
\text { (Samadia, 2005). }\end{array}$} \\
\hline
\end{tabular}

\section{Performance of male sterile and restoral lines}

Plant height

The high yielding ability of a variety depends upon some important plant characteristics short stature is one of them. Plant height may not have significant role to play in the expression of hybrid vigor (Dwivedi, 1985) but semi dwarf plant type is desire because they show some what resistance against not only lodging but also other yield increasing character. At maturity, plant height (from soil surface to unbent plant tip) among the

\begin{tabular}{llllll} 
VP & GCV & GPV & GEV & h$^{2} \mathrm{~B}$ & GA \\
\hline 13.55 & 2.91 & 3.43 & 1.68 & 76.01 & 5.76 \\
8.23 & 9.32 & 17.08 & 19.46 & 77.03 & 17.83 \\
7.07 & 5.40 & 7.07 & 4.57 & 58.27 & 3.19 \\
6.87 & 6.96 & 10.25 & 7.51 & 46.14 & 2.49 \\
7.02 & 8.01 & 7.20 & 5.14 & 70.79 & 5.10 \\
2.28 & 1.35 & 1.46 & 0.54 & 85.96 & 2.67 \\
319.35 & 12.34 & 12.73 & 3.13 & 93.95 & 2.82 \\
23.48 & 16.14 & 16.84 & 4.82 & 91.80 & 5.14 \\
& & & & & \\
83.45 & 3.98 & 4.15 & 1.16 & 92.16 & 17.34 \\
\hline
\end{tabular}

GCV $=$ Genotypic coefficient of variance $\mathrm{PCV}=$ Phenotypic coefficient of variance $\mathrm{ECV}=$ Environmental coefficient of variance $\mathrm{GA}=$ Genetic advance

RGBU009A was significantly the tallest among them with a height of $114.0 \mathrm{~cm}$, which was statistically not identical with Gold $\mathrm{R}$ but significantly different with the other varieties. $F_{1}$ obtain between them may be the tallest one which is not our desired due to unwanted lodging. Medium height plant is our target to consider this objective. So RGBU003A and RGBU012A may be selected to cross with restorer parent SL8R or Mitali R. Ali et al. (2000) have observed relatively greater range in plant height than the other characters.

Number of effective and ineffective tillers per hill

Productive tillers are an important yield component for rice. Number of panicle is believed to be closely associated with number of effective tiller so, the hybrids with more number of effective tillers are our desired. The variety or hybrid with low tillering capacity is not wanted in transplanted rice culture. 
Table 4. Comparison of some agronomically important trait for rice cultivation.

\begin{tabular}{llllllll}
\hline & $\begin{array}{l}\text { Plant } \\
\text { Height }(\mathrm{cm})\end{array}$ & $\begin{array}{l}\text { Number of } \\
\text { effective } \\
\text { tiller/ Hill }\end{array}$ & $\begin{array}{l}\text { Number of } \\
\text { ineffective } \\
\text { tillers/ Hill }\end{array}$ & $\begin{array}{l}\text { Length of } \\
\text { normal leaf } \\
(\mathrm{cm})\end{array}$ & $\begin{array}{l}\text { Length of } \\
\text { flagleaf(cm) }\end{array}$ & $\begin{array}{l}\text { Length of } \\
\text { panicles } \\
(\mathrm{cm})\end{array}$ & $\begin{array}{l}\text { Maturity (days } \\
\text { after } \\
\text { transplanting) }\end{array}$ \\
\hline RGBU002A & $109.3 \mathrm{bc}$ & $14.33 \mathrm{~d} d$ & $13.23 \mathrm{c}$ & $40.60 \mathrm{ab}$ & $26.13 \mathrm{bc}$ & $25.60 \mathrm{bc}$ & $158.33 \mathrm{~b}$ \\
RGBU003A & $106.3 \mathrm{~d}$ & $19.7 \mathrm{a}$ & $18.8 \mathrm{a}$ & $41.57 \mathrm{ab}$ & $21.27 \mathrm{e}$ & $25.14 \mathrm{c}$ & $162.7 \mathrm{ab}$ \\
RGBU005A & $106.3 \mathrm{~d}$ & $12.4 \mathrm{~d}$ & $13.10 \mathrm{~cd}$ & $33.00 \mathrm{c}$ & $26.00 \mathrm{bc}$ & $26.53 \mathrm{bc}$ & $149.7 \mathrm{c}$ \\
RGBU006A & $109.1 \mathrm{bc}$ & $17.40 \mathrm{~b}$ & $17.33 \mathrm{ab}$ & $35.00 \mathrm{bc}$ & $28.93 \mathrm{ab}$ & $25.20 \mathrm{ab}$ & $152.3 \mathrm{bc}$ \\
RGBU009A & $114 \mathrm{a}$ & $19.70 \mathrm{a}$ & $18.18 \mathrm{ab}$ & $40.33 \mathrm{ab}$ & $22.33 \mathrm{de}$ & $27.20 \mathrm{bc}$ & $138.0 \mathrm{~cd}$ \\
RGBU010A & $106.2 \mathrm{~d}$ & $16.07 \mathrm{bc}$ & $15.33 \mathrm{~b}$ & $40.90 \mathrm{ab}$ & $27.83 \mathrm{bc}$ & $26.6 \mathrm{bc}$ & $134.7 \mathrm{~d}$ \\
RGBU012A & $105.7 \mathrm{e}$ & $15.1 \mathrm{c}$ & $14.7 \mathrm{bc}$ & $40.67 \mathrm{ab}$ & $22.21 \mathrm{de}$ & $26.50 \mathrm{bc}$ & $135.7 \mathrm{~d}$ \\
RGBU013A & $105.7 \mathrm{e}$ & $11.57 \mathrm{~d}$ & $11.13 \mathrm{~d}$ & $36.30 \mathrm{~b}$ & $25.67 \mathrm{c}$ & $25.80 \mathrm{bc}$ & $139.0 \mathrm{~cd}$ \\
RGBU014A & $106.1 \mathrm{~d}$ & $10.50 \mathrm{e}$ & $15.10 \mathrm{bc}$ & $40.60 \mathrm{ab}$ & $23.46 \mathrm{~d}$ & $25.14 \mathrm{c}$ & $169.7 \mathrm{a}$ \\
SL 8R & $107.2 \mathrm{~cd}$ & $14.80 \mathrm{~cd}$ & $8.00 \mathrm{e}$ & $40.60 \mathrm{ab}$ & $30.13 \mathrm{ab}$ & $34.60 \mathrm{ab}$ & $158.33 \mathrm{~b}$ \\
LP70R & $112.2 \mathrm{~b}$ & $8.2 \mathrm{f}$ & $8.00 \mathrm{e}$ & $41.57 \mathrm{ab}$ & $30.27 \mathrm{a}$ & $30.17 \mathrm{~b}$ & $162.7 \mathrm{ab}$ \\
Mitali R & $108.7 \mathrm{c}$ & $14.27 \mathrm{dd}$ & $10.03 \mathrm{de}$ & $43.20 \mathrm{a}$ & $28.00 \mathrm{~b}$ & $30.53 \mathrm{ab}$ & $149.7 \mathrm{c}$ \\
Gold R & $112.6 \mathrm{~b}$ & $11.07 \mathrm{de}$ & $10.93 \mathrm{de}$ & $43.00 \mathrm{a}$ & $28.93 \mathrm{ab}$ & $35.20 \mathrm{a}$ & $152.3 \mathrm{bc}$ \\
\hline
\end{tabular}

*Means of the same letter are not significantly different at 5\% level by DMRT

The data from Table 4 showed that RGBU002 A, SL8 R and Mitali R produced more or less same number of productive tillers/hill, which was statistically identical with each other. RGBU003 A and RGBU009 A produced the lowest number of productive tillers. So it is not applicable to select them in transplanting rice breeding programme for this character. In case of ineffective tiller RGBU013A, SL8R and LP70 R performed minimum number of ineffective tiller can be selected to obtain desirable $\mathrm{F}_{1}$. Alam et al. (2000), Jarwar et al. (2013), J anardhanam et al. (2001) and Liakat (2011) also agree with this finding.

Length of normal leaf, flag leaf and panicle

Increased the leaf blade area increases the photosynthetic area. Flag leaf area is also important because it directly supplies food and nutrients as well as it protect the panicle as early stage. Plants are generally characterized by having longer panicles indicating their efficiency in partitioning of assimilates to reproductive parts. To select desirable parent to obtain our target $\mathrm{F}_{1}$ we also consider that erect type plant accumulate maximum sun light. Long leaf is the result of interception of direct sunlight that has negative effect on photosynthetic rate. The longest leaf blade was found in parent LP70R $(41.57 \mathrm{~cm})$ and the shortest leaf blade was found in plant RGBU005A $(33.00 \mathrm{~cm})$. In case of flag leaf length the longest flag leaf was found in the plant LP70R (30.27 cm) and shortest flag leaf was found in the plant RGBU003A $(21.27 \mathrm{~cm})$. For panicle, length all restoral lines other than LR70R are statistically similar to each other, which can selected due to their superior performance (Table 4). Liakat (2011) also conduct same type of experiment which result also reflects this finding.

\section{Days to maturity}

Heading time is an important agronomic character, which determines the regional and seasonal adaptability of rice varieties. Development of early maturing and high yielding varieties is one of the important objectives in rice breeding (Peng et al., 1995). Short duration plant is our desired so that they can easily adjust to the cropping pattern. It also needs to reduce input cost. From the Table 4, we find that RGBU014 a required maximum day to mature followed by RGBU009A, RGBU005A, RGBU010A, RGBU012A and LP70 R. We also obtain RGBU010A, RGBO012A and RGBU013A are earlier than other. In case of restorer line, Mital $\mathrm{R}$ is earlier from other. So, they can select to obtain this trait for future rice breeding programme.

Number of primary and secondary branches per panicle

Number of primary branches per panicle is another important component of yield and probably this character will be helpful in breaking the yield ceiling (Singh and Maurya, 1999). The highest number of primary branches per panicle was found in RGBU002A $(11.36 \mathrm{~cm})$ which was followed by SL8R $(11.33 \mathrm{~cm})$ and the lowest number of primary branches was found in RGBU010A (7.39 cm) followed by RGBU009A $(7.80 \mathrm{~cm})$. On the other hand highest number of secondary branch was found in the parent Mitali R $(39.27 \mathrm{~cm})$ and the lowest number of secondary branches was found in the plant RGBU002A (19.11 cm) followed by RGBU014A (19.59 cm). To obtain maximum no. of primary and secondary branch/ panicle RGBU013A, RGBU014A, Mitali R and SL8R may be superior to other.

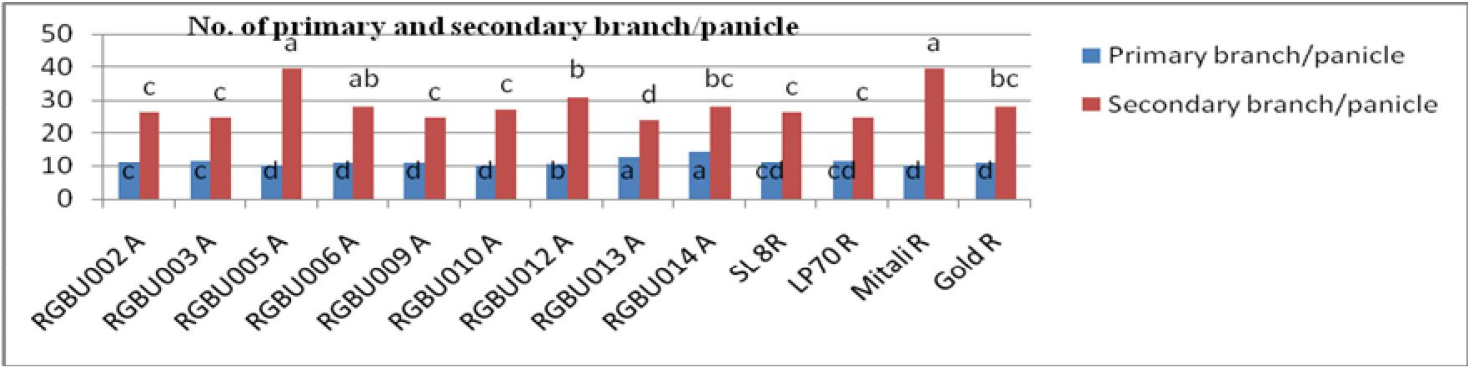

*Means of the same letter are not significantly different at 5\% level by DMRT

Fig. 1. Average number of primary and secondary branches/panicle. 
Number of filled and unfilled grain per panicle

For filled and unfilled grain only restoral line were considered. Maximum number of filled grain production per panicle was recorded in the parent SL8R followed by Mitali $\mathrm{R}$ and lowest number of filled grain production per panicle was found in the parent LP70R followed by Gold $\mathrm{R}$.

Table 5. Average number of filled and unfilled grain per panicle and yield.

\begin{tabular}{lccc}
\hline Name of Entry & No of filled grain/panicle & No of unfilled grain/panicle & Yield(t ha-1) \\
\hline SL 8R & $163.2 \mathrm{a}$ & $16.93 \mathrm{c}$ & $4.63 \mathrm{~b}$ \\
LP70 R & $145.9 \mathrm{~b}$ & $19.30 \mathrm{~b}$ & $4.70 \mathrm{a}$ \\
Mitali R & $161.9 \mathrm{a}$ & $25.27 \mathrm{a}$ & $4.85 \mathrm{a}$ \\
Gold R & $144.3 \mathrm{~b}$ & $19.23 \mathrm{~b}$ & $4.53 \mathrm{~b}$ \\
\hline
\end{tabular}

*Means of the same letter are not significantly different at 5\% level by DMRT

Higher number of unfilled grains per panicle was found in the parent Mitali R followed by LP70R and lowest number of unfilled grain per panicle was found in the parent SL8R.

Finally, it can be concluded that yield is more or less similar for the entire meal or pollen parent. But to obtain ideal plant type we need to consider other agronomically important trait like days to maturity, length of flag leaf, number of filled grain with medium height RGBU003A, RGBU012A may be superior as a female parent where SL8R as a restorer parent. Considering other yield contributing character RGBU006A, RGBU009A, RGBU010A may be considered as superior female parent to cross with any other restorer line.

\section{References}

Alam, M.F., Ahmed G.D., Shohel, A.M., Biswas M.K. and Amin, M.R. 2000. Study on parental variability and heterosis on rice. Pakistan J. Biol. Sci. 5 (10): 1006-1009.

Ali, S.S., J afri, S.J.H., Khan, T.Z., Mahmood. A. and Butt, M.A. 2000. Heritability of yield and yield components of rice. Pak. J. Agric. Res. 16: 89-91.

Anonymous. 1989. Annual Weather Report, Meteorological station, Bangabandhu Sheikh Mujibur Rahman Agricultural University, Salna, Gazipur. pp. 14-22.

Anonymous. 2010. Annual Report of Bangladesh Rice Research Institute. Gazipur 1701, Bangladesh. p. 34.

Babu, V.R., Shreya, K., Dangi, K.S., Ushsrani, G. and Nagesh, P. 2012. Genetic studies for qualitative and quantitative traits in popular rice (Oryza sativa L.) hybrids India. Int. J. Sci. Res. Pub. 2(6): 18-22

Brown, L.R. 1994. State of the world. W.W. Norton and Company. New York. 149p.

Dwivedi, J.L. 1985. Heterosis in rice and its exploitation. In: Genetics and Rice
Improvement. National Symposium held at Directorate of Rice Research, Hyderabad, India, 17-18 Aug. 1985.

Janardhanam, V., Nadarajan, N. and Jebaraj, S. 2001. Studies on heterosis in rice (Oryza sativa L.). Indian Agril. J. 88(10/12): 721723.

Jarwar, A.D., Dela Cruz, Q.D. and Junejo, G.S. 2013. Heterosis of some yield and its related characters in aromatic rice (Oryza sativa L.) varieties and their F1 hybrids under lowland and upland environments. Pak. J. Agri. Agril. Engg. Vet. Sci. 29 (1): 13-23.

Liakat. 2011. Heterosis in selective combination of $\mathrm{A}$ and $\mathrm{R}$ lines in rice (Oryza sativa). M.Sc.(Ag). Dissertation, Bangabandhu Sheikh Mujibur Rahman Agricultural University. Bangladesh. pp. 42-59.

Peng, J., He, Y. and Liu, B. 1995. A new dominant earliness character of CMS line Zaoxian A and its application value in rice (Oryza sativa L). Euphytica. 81: 235-244.

Samadia, D.K. 2005. Genetic variability studies in Lasora (Cordia myxa Roxb.). Indian J. Plant Gen. Res. 18(3): 236-240.

Sao, A. 2002. Studies on combining ability and heterosis in F1 rice hybrids using cytoplasmic male sterile lines, M. Sc. (Ag.) Thesis, IGAU, Raipur, India. pp. 52-55.

Singh, B.D. 2000. Centre of origin. Plant Breeding Kalyani Publishers. New DelhiLudhiana India. pp. 27-31.

Singh, M. and Maurya, D.M. 1999. Heterosis and inbreeding depression in rice for yield and yield components using CMS systems. Oryza 36: 24-37.

Virmani, S.S. 1996. Genetic diversity in the parental lines and heterosis of the tropical rice hybrids. Int. Rice Res. Inst. Metro Manila, Philippines. 57: 377-461. 